Sir William Orpen's To the Unknown British Soldier in France:

a controversial commemoration

Amy Lim

University of Oxford

amy.lim@st-hildas.ox.ac.uk

amyplusthree@twitter.com

ORCID iD: https://orcid.org/0000-0003-1359-6862

Word count: 7982 


\section{Sir William Orpen's To the Unknown British Soldier in France: a controversial commemoration}

\section{Abstract}

This article considers Sir William Orpen's controversial painting To the Unknown British Soldier in France as a site of memory in the decade following the armistice. War art played a part for many people in helping to make sense of and commemorate the war, but expectations of how art could and should do this varied between different groups and changed over time. In the later war years and immediately post-war, art produced by eyewitnesses to the conflict was valued for the truth of its testimony; however, there were different interpretations of what this meant in practice. While the Imperial War Museum sought to create a factual record of events, the majority of the public and press expected war art to tell a symbolic rather than literal truth. To the Unknown British Soldier in France was commissioned by the IWM in 1919 to commemorate the Versailles peace conference and was most expensive art commission of the war. Unveiled to a storm of controversy in 1923, it was rejected by the museum and subsequently altered by Orpen before its eventual acceptance in 1928. Orpen turned the commission into his personal commemoration of the ordinary soldier, whom he felt had been forgotten in the peace process. The painting juxtaposed spectral, decaying soldiers with a realistic, flag-draped coffin, and while this hybrid style offended some, many others warmly approved, believing that it was important to acknowledge the horrors of war even within a memorial context. This episode suggests that in the immediate post-war years, the genres of avant-garde/critical and traditional/memorial art were not mutually exclusive, and that many people wanted to honour the memory of the fallen, whilst simultaneously acknowledging the harsh realities of war.

Keywords: Orpen, Imperial War Museum, eyewitness, war art, memorial 
Art played a vital role in helping people to express and make sense of the heightened emotions and often traumatic experiences of the First World War. Since the 1990s, when Jay Winter first applied Pierre Nora's concept of lieux de mémoire to the war, works of literature, music and the visual arts have increasingly been analysed for the insights that they can bring, especially to studies of memory. ${ }^{1}$ They are valued both for the historical memory they encapsulate at the point of their creation, and for their afterlives as agents of cultural memory. ${ }^{2}$ Fine art in Britain during and immediately after the war was distinct from the majority of peacetime art in being principally a public activity. It was mostly commissioned by public bodies and publicised through officially-sanctioned reproductions, exhibitions, and the new Imperial War Museum (IWM), and through this control of access, funding, and display, they were able to exercise a degree of control over how the war was depicted. ${ }^{3}$ The monumental sculpture and painting that was created in the immediate post-war years was more fragmentary, commissioned by thousands of separate municipal bodies, military organisations and other groups, but it too was mostly commissioned by committees for public benefit. The public circumstances in which war artworks were created and received made them sites of memory for a wide range of people, making them especially useful windows onto contemporary attitudes and values.

The idea of the artist as eyewitness was inextricably bound up with the production of war art. Eyewitnesses to the conflict were accorded special status as their experiences were held to convey a special truth about war, and eyewitness accounts dominated the discourse of remembrance. ${ }^{4}$ But in war art, as Jennifer Wellington has observed, the meanings of 'eyewitness' and 'truth' could vary. For the commissioners of war art in 
Canada and especially Australia, it meant the faithful reproduction of locations and events, preferably in a traditional figurative style. ${ }^{5}$ Margaret Hutchison, in her account of the Australian War Museum's interventionist commissioning of Harold Septimus Power's Saving the Guns of Roubecq, has demonstrated how in Australia such literal depiction took precedence over aesthetics, even at the expense of emotional impact. ${ }^{6}$ In Britain, however, the notion of truth in art was interpreted much more broadly. In part, this was because artistic freedom was considered to be an expression of Britain's liberal values. Charles Masterman's War Art Scheme and Arnold Bennett's British War Memorials Committee both commissioned significant bodies of art in which they prioritised aesthetics over propaganda, deliberately giving artists a free hand. The artist was valued not only as recorder but also creator, able 'to convey higher artistic or aesthetic truths about the nature and experience of war'. The IWM's policy, however, was more in line with that of Australia and Canada. It aimed to comprehensively document all aspects of the war, which was to take priority over artistic expression. ${ }^{8}$ The museum's art sub-committee was dominated by representatives of the armed forces and wartime ministries, and the works they commissioned and acquired tended to represent a military viewpoint, rather than that of the ordinary combatant or civilian.

Artistic style and definitions of truth were linked to interpretations of the war itself. Avant-garde art became associated with a critical exposé of the horrors of war, led by youthful artists such as C.R.W. Nevinson, Percy Wyndham Lewis and Paul Nash, all of whom had served on the western front. Their disenchantment was most famously expressed in Paul Nash's letter to his wife Margaret, in which he avowed, 
I am no longer an artist interested and curious, I am a messenger who will bring back word from the men who are fighting to those who want the war to go on forever. Feeble, inarticulate will be my message, but it will have a bitter truth, and may it burn their lousy souls. ${ }^{9}$

When their work was exhibited in May 1918, these artists' stark interpretations of what they had experienced were considered to have 'found the essentials of it' ${ }^{10}$ After the war, as millions of people struggled to come to terms with trauma and bereavement, memorial sculpture was almost exclusively expressed in the conventional language of glory, mourning and Christian sacrifice. Samuel Hynes, in A War Imagined, divided art and other creative works into two parallel currents running through the 1920s: the creation of monuments, which embodied traditional concepts of glory and heroism, and anti-monuments, which 'turned away from celebration, in search of reality'. ${ }^{11}$

The analysis of one single, but important, painting that is the focus of this article, suggests that this division was not so clear cut. Sir William Orpen's To the Unknown British Soldier in France straddled the boundaries of traditional memorial and avantgarde art, combining the rhetoric of Christian sacrifice with images of death and putrefaction (fig. 1). [figure 1 near here] Commissioned by the IWM in 1919, together with its two companion pictures it was, at $£ 6,000$ ( $£ 304,000$ in today’s money) by far the most costly art commission of the war. ${ }^{12}$ It generated a storm of controversy on its unveiling in 1923, and was initially rejected by the museum, eventually being accepted, after alteration, in 1928. It remains on permanent display at the IWM in London and is mentioned in most art histories of the war, but despite the painting's prominence and the subsequent furore it has not hitherto been examined in depth, 
despite an unusually rich body of sources in the IWM archives, press, public and private correspondence and the artist's own papers. ${ }^{13}$ To the Unknown British Soldier in France became an important site of memory in the decade after the armistice, around which a range of views coalesced, from the political to the personal, from the romantic to the radical, from the left to the right, from the prime minister to the exsoldier. The painting became a battleground for competing interpretations of eyewitnessing, truth, and the appropriate manner in which to understand and memorialise the war.

\section{Painting the peace conference}

William Orpen was something of an outlier among the war artists. A Londonbased Irishman, aged 36 on the outbreak of war, he was more than a decade older than Nash and Nevinson, and, unlike them, did not serve in either a military or medical capacity. ${ }^{14}$ As an Associate of the Royal Academy, and earning a substantial income as Britain's leading portrait painter, nor could he be classed among them stylistically. On the other hand, Orpen was keen to distinguish himself from older artists such as John Singer Sargeant who spent only three weeks at the front before painting his vast canvas Gassed (1918-9). In 1917 Orpen was recruited as an official war artist, his fame and high-placed connections securing him the rank of Major in the Army

Service Corps and special dispensation to stay at the front indefinitely. ${ }^{15}$ From April 1917 to the following spring he spent all but three months in France, at and behind the front lines, observing, sketching, and painting. The shattered landscape made a profound impression on his artist's eye, but he was even more moved by the people 
he met, of all stations: generals, airmen, ordinary tommies, French civilians. ${ }^{16}$ His large output of war paintings included traditional portraits but also desolate, bleached landscapes, decaying bodies, and scenes such as The Mad Woman of Douai (1918) that confronted the psychological impact of war on soldiers and civilians. ${ }^{17}$ In May 2018, 125 of his paintings were shown in a monograph exhibition entitled 'War' at Agnews in London and subsequently in Manchester, attracting large crowds but only lukewarm reviews. Critics complained of a lack of emotion, Claude Phillips writing in the Daily Telegraph that Orpen's paintings were 'more sincere and downright than truly imaginative'. ${ }^{18}$ Already, many critics expected an artist's interpretation of war to be emotional rather than representative. Nevertheless, in June 1918 Orpen was made a Knight of the British Empire, and the following month Sir William Orpen returned to France where he remained throughout the remainder of the war and into 1919.

No sooner was the armistice signed than the IWM began preparations to record the peace process on canvas. Orpen was keen to undertake the commission, writing 'I would do the conference room at Versailles with pleasure and interiors with the conference going on with delight', and by 19 November he had been authorised by a joint committee of the Ministry of Information and the IWM to paint 'an important picture of the forthcoming Peace Conference', although there was no specific brief. ${ }^{19}$ In February 1919, Lloyd George intervened. His private secretary wrote to Commissioner of Works Sir Alfred Mond that, 'It was considered by the Prime Minister that the Peace Conference ought not to be allowed to pass without some suitable and permanent memento having been made of these gatherings.' Orpen, along with Augustus John, 'two of the most famous of British Artists' were 
appointed, with 'The Government to have the option of purchasing the pictures when completed for the War Museum: the sum of $£ 3,000$ to be paid for each work', an unprecedented sum for a war art commission. ${ }^{20}$ John's work never materialised, but by March, Orpen was planning not one but three paintings. He proposed to paint the 'Conference room with about 6 of the leading figures...Ante Room=with about 30 figures' and 'Signing of Peace. Hall of Mirrors=about 30 figures' ${ }^{21}$ The IWM understandably baulked at the potential cost, suggesting that they might only choose one of these paintings. ${ }^{22}$ In response Orpen, whose financial situation was now precarious (he had been subsisting only on army pay for two years and was incurring heavy expenses in Paris), pointed out that he was hardly likely to find another buyer, and so on 2 May 1919 the IWM Committee 'unanimously agreed that we should purchase the three pictures which you are executing to illustrate the Peace Conference, at an inclusive price of $£ 6,000,{ }^{23}$ The iterative process of arriving at this brief left it riddled with contradictions. Both the IWM and the Prime Minister expected a factual representation of the conference, but Orpen, who had been schooled in Masterman's laissez-faire War Art Scheme, was to be given a free hand with composition. The IWM had committed only to an option to purchase, but subsequently had agreed to purchase all three canvases. It was to open the door to host of problems further down the line.

As Orpen witnessed the peace negotiations he became increasingly disillusioned. His first two paintings reflected his growing cynicism. In A Peace Conference at the Quai d'Orsay and The Signing of the Peace in the Hall of Mirrors (fig. 2) the statesmen are reduced to diminutive figures, whilst the Baroque grandeur and vast mirrors hint at his view of the empty ceremony. [figure 2 near here] During 
his time at the front, Orpen had come to greatly admire the stoic heroism of the ordinary British soldier and believed he was being forgotten in the political wrangling. In his memoir, An Onlooker in France, published in 1921, his bitterness seeps into his description of the signing:

\begin{abstract}
All the frocks did their tricks to perfection. President Wilson showed his back teeth; Lloyd George waved his Asquithian mane; Clemenceau whirled his greygloved hands about like windmills; Lansing drew his pictures and $\mathrm{Mr}$ Balfour slept. It was all over. The frocks had won the war. The frocks had signed the Peace! The Army was forgotten. Some dead and forgotten, others maimed and forgotten, others alive and well - but equally forgotten. ${ }^{24}$
\end{abstract}

When the first two paintings were shown at the Royal Academy's Summer Exhibition in 1920, critics recognised the intended irony, but they were accepted by the IWM without demurral. ${ }^{25}$ Orpen's third painting was to be less well received.

Throughout 1920 and into 1921 Orpen remained in Paris after the departure of the principal delegates, working on his third and final painting. This one was to feature military leaders as well as politicians, waiting in the Hall of Peace to enter the Hall of Mirrors for the signing. He worked hard to arrange the figures, but already an element of fantasy was creeping in. In a letter probably written in December 1920 he included a sketch of the composition with some of the key figures identified. ${ }^{26}$ Along with Lloyd George, Clemenceau, Haig, Foch and French are to be found Lieut. Rhys Davids, the flying ace, and a Grenadier Guardsman, both painted by Orpen in 1917. They represented the courageous airmen and ordinary soldiers Orpen admired so much. Orpen knew that he was straying from the brief, writing 'perhaps the IWM 
won't like it. ${ }^{, 27}$ Eventually, after nine months of painstakingly arranging and painting the individual portraits, Orpen rebelled. He painted out all the figures, and replaced them with a flag-draped coffin, flanked by a ghostly guard. This he named To the Unknown British Soldier in France.

Orpen's painting is a disturbing hybrid of realism and allegory. Against the detailed backdrop of the Hall of Peace is a purely imaginary foreground assembly. In the lower centre of the composition, Orpen painted a coffin draped with a Union Jack and surmounted with a tin hat. Beyond, a pathway of light leads through a dark hall to a crucifix silhouetted in an archway. Flanking the coffin Orpen painted two ghostly, emaciated and semi-nude soldiers with rifles, and hovering above them two cherubs holding garlands of flowers. Although only black and white photographs of the original painting now remain, contemporary descriptions of the soldiers refer to their colour as green, or 'putrefying flesh'. ${ }^{28}$ These phantasmagorical figures can be, and were, interpreted as mad or dead, or both. Their sinuous stances are taken from Orpen's 1917 drawing Blown Up (fig. 3) of a soldier whom Orpen found stumbling through ruins, his clothes blown away by an explosion, 'out of his mind' and 'raving'. ${ }^{29}$ [figure 3 near here] These figures drew heavily on classical models, lending them an allegorical quality. Whilst the soldiers do not realistically depict decaying bodies, their skin tone clearly hints at their ultimate end. The figures are disturbing not only because they acknowledge the reality of death and insanity in war, but because their ghostly madness contrasts with the dignified realism of the catafalque. Their incongruity makes it a profoundly unsettling picture. 
In making these changes, Orpen transformed the canvas from a factual record of the conference to a work of the imagination. It became Orpen's tribute to the ordinary soldiers he had admired so much during his time in France. Throughout An Onlooker in France, and in later interviews with the press, Orpen reiterated his admiration for 'the common British soldier, the greatest figure of all' ${ }^{30}$ By painting the Unknown Soldier's coffin in the dignified setting of Versailles, Orpen was metaphorically exhuming and reburying the desecrated corpses that littered the western front. The flag-covered coffin, the crucifix and cherubs are drawn directly from conventional mourning imagery. Such tropes were prevalent in popular art during the war, and although they are sometimes dismissed as merely sentimental, Peter Harrington has shown how such imagery served as a coping mechanism. ${ }^{31}$ This consoling rhetoric continued to be a popular choice for the thousands of war memorials that were being erected as Orpen worked on his picture. The painting was Orpen's personal act of commemoration, a way of coming to terms with the profound effects of what he had seen in France, but enacted in a public forum.

The painting was also Orpen's commentary on the peace process and the aftermath of war. As an Irish-born Protestant who had penetrated to the heart of the British establishment, Orpen avoided politics to the point of deliberate naivety, but nevertheless he could not fail to be aware of the social and economic circumstances that made it apparent that Lloyd George's 'home fit for heroes' had not materialised. At Christmas 1921, as Orpen worked on the painting, unemployment stood at over two million, or nearly $18 \%$, and medal-wearing unemployed ex-servicemen begged on the streets of London. ${ }^{32}$ In the same year Orpen's annual income rocketed to over $£ 40,000$, around five times his typical pre-war earnings. ${ }^{33}$ Despite refusing to profit 
either from his war work or An Onlooker in France, he must have been painfully aware of the discrepancy. ${ }^{34}$ The replacement of the dignitaries with the coffin was Orpen's public commentary on how the ordinary soldier had been forgotten in the wrangling and posturing of the peace negotiations.

To the Unknown British Soldier in France was also influenced by other artistic and literary responses to the war. Orpen was impressed by war correspondent Philip Gibbs' searing memoirs, Realities of War and Back to Life, describing them as 'very very true and real. ${ }^{35}$ He would also have been aware of some unfavourable criticism of his war paintings. Several of his works were exhibited at The Nation's War Paintings in December 1919, and while Orpen's visions of madness and horror were warmly commended by Middleton Murry in the Nation, a stinging review in the Athenaeum divided the exhibits into "pictures by men who were tortured by the war and the pictures by men who were not', with Orpen cited as a prime example of the latter. ${ }^{36}$ Orpen may not have served as a combatant but his lengthy stay on the western front brought him a depth of experience not shared by most of the older generation of artists, and he was keen to assert the authenticity of his witness. At the other end of the artistic and political spectrum, Frank Salisbury's The Burial of the Unknown Warrior, Westminster Abbey, 1920, commissioned by the House of Commons and painted in a realistic and traditional style, was enjoying popular success and was even praised by the king. ${ }^{37}$ To the Unknown British Soldier in France was neither avantgarde nor conventional, blending representation and imagination, realism and allegory. Combining images of death and decay with traditional Christian imagery, this stylistic hybrid proved to be surprisingly popular with the public. 


\section{The press and public reaction}

To the Unknown British Soldier in France was unveiled on Friday 4 May 1923 at the private view of the Royal Academy Summer Exhibition, where it was the sensation of the show, gathering large crowds and receiving widespread press coverage the following day. ${ }^{38}$ Since the pre-war years, the press had been accustomed to find a 'problem picture' that could not be easily interpreted, and many newspapers lighted on Orpen's painting as that year's puzzle. Immediate reactions to the painting fell broadly into three camps. The first, predominantly conservative group disliked the painting on the basis that it offended the sacred memory of the fallen. Many other papers were neutral or uncomprehending, while a third group understood the message Orpen was trying to convey and praised its honesty. Over the course of the following two weeks, these initial assessments polarised in line with the newspapers' stance towards the war.

Hostile reactions by the press to the painting centred on the discord between the guarding soldiers and the conventions of memorial art. Several newspapers, all conservative in outlook, objected to the picture on these grounds. Under the subheading 'Desecration', the Morning Post considered that the picture 'will offend many people,' continuing, 'It is difficult to write of this picture with reserve.' ${ }^{39}$ The Daily Mail was 'shocked' by the soldiers and felt that the picture 'reveals an almost flippant spirit altogether out of keeping with the solemn, sacred significance of the subject. ${ }^{40}$ A Westminster Gazette correspondent strongly condemned the painting as 'shameful, it robs war of all its glory.' 41 These newspapers implied that by including 
the grotesque figures, Orpen had breached the etiquette of commemoration, which carefully avoided references to the physical actualities of death.

Some liberal and left-wing papers wrote just as vehemently about To the Unknown British Soldier in France, claiming it to be a criticism of the glorification of war and the failure of the peace-makers. On Monday 7 May the Liberal Daily News came out strongly in favour of the painting, with a large front-page article. It explained Orpen's sentiments, criticising 'the politicians who crept from their lurking places when the last shot had been fired,' and emphasised his eyewitness status: 'He knows. He was there' [original emphasis]. ${ }^{42}$ It was, of course, referring not to Orpen's presence at the peace conference, but the western front. The journalist sarcastically suggested that Orpen's critics would have preferred 'a picture of the tomb of the Unknown Warrior in Westminster Abbey, surrounded by white-robed clergy, staff officers and statesmen with bowed heads' (in other words, Salisbury's painting), and attacked the position of the conservative press, writing, 'He shares with the ex-soldier a bitter hatred of the conventional pageantry with which those who know nothing of war like to surround it. ${ }^{43}$ The Labour-supporting Daily Herald, which had been an outspoken critic of the Treaty of Versailles, took a very similar line. It too criticised 'convention, sham and false heroics' and grounded Orpen's authority in his eyewitness status, concluding, 'They particularly object to the greenish flesh colouring. But perhaps they have not, like Sir William, seen what happens to a body which has been lying on the battlefield for some hours. ${ }^{44}$ These articles could be characterised as anti-war, hostile to its glorification through the pageantry of commemoration and equally hostile to the politicians who had made the peace, and they claimed Orpen's painting as an expression of these sentiments. 
A number of newspapers, including the Daily Express, Manchester Guardian and Hull Daily Mail took a more balanced political stance, but understood Orpen's intentions and praised To the Unknown British Soldier in France for its honesty. ${ }^{45}$ As with the Daily News and Daily Herald, these newspapers highlighted Orpen's eyewitness credentials, which gave authenticity to his pictorial testimony. The Manchester Guardian, responding to the suggestion that the IWM might not take the painting, argued that, 'a war picture, so deeply felt by the artist that he destroyed months of his work and went straight in the face of his commission to express an overmastering message to his generation is unique.' It argued that its heartfelt emotion meant that 'it is of all pictures the one most necessary for the War Museum. ${ }^{46}$ While these newspapers sympathised with Orpen's critique of the disappointments of the post-war years they stopped short of being anti-war. As the Observer pointed out, 'The war was not wrong because the peace was wrong...With all our might we must protest against the thesis that a million men of this Empire laid down their lives for nothing., ${ }^{, 4}$

Orpen himself was not a silent bystander during these debates. He was distressed by the accusations of flippancy and gave a number of interviews, most notably with the Evening Standard, which appeared as its headline article on 7 May 1923 and was widely reproduced in other newspapers. ${ }^{48}$ Orpen described how he had painted the politicians, generals and admirals, saying, 'And then, you know, I couldn't go on. It all seemed so unimportant somehow beside the reality as I had seen it and felt it when I was working with the armies.' Protesting his sincerity, he said, 'An artist's duty is not to paint what is pleasant but to paint what is true', and described 
the "many letters from men who served in France congratulating me on the picture, and agreeing that the symbolism was true.' Orpen reiterated the view that his presence on the western front (albeit non-combatant) had given him a special right to speak out the truth. Neither he nor the press considered 'truth' to mean a literal record of what he had seen. His role as artist-eyewitness was to convey a deeper meaning through artistic interpretation. Orpen, still feeling that his views had been misrepresented, then authored an article in the English Review. Ignoring the painting's awkward elements, he focused only on the memorial aspect, using notably traditional language. He referred to 'the wreath of victory' and disingenuously described the soldiers only as 'dead comrades', concluding that 'their anonymous work will always testify to the glory of their lives', perhaps in an effort to distance himself from the politicised interpretations of his painting. ${ }^{49}$

The public reception of artworks can be difficult to gauge, but responses to Orpen's painting are well documented. Many newspapers reproduced photographs of To the Unknown British Soldier in France, so a large number of people beyond the visitors to the exhibition had the opportunity to see it and judge for themselves. ${ }^{50}$ By 7 May, several papers, including the front page of the Daily Graphic, were referring to the painting as 'Picture of the Year', an informal designation granted on the basis of popularity. ${ }^{51}$ It also provoked considerable correspondence from war veterans, bereaved parents and other interested members of the public. Letters to the press were mostly supportive, letters to Orpen overwhelmingly so. Each correspondent brought their own preoccupations to the picture and interpreted it accordingly. Some read the picture as a Christian parable of sacrifice, with one correspondent writing that, 'the soul of the soldier has passed through the dark corridor to a glorious Beyond, 
illuminated by the shining cross. ${ }^{52}$ For others, the picture reminded them of dead comrades or sons. A disabled veteran wrote to Orpen, 'In my humble opinion I think it is a national memorial to those who won the War by the giving of their lives in the cause of freedom. ${ }^{53}$ Another wounded officer wrote movingly of his 'three other school chums' with whom he had gone to France, 'facing horrors unheard of'; all had been killed, and for him the cherubim 'seem to be my two friends standing there guarding my third. ${ }^{54}$ Not only did the ghostly nature of the soldiers not trouble the correspondents, who accepted them as a matter-of-fact representation of the dead, but they were even seen as sympathetic guarding spirits. All these correspondents used the traditional, quasi-spiritual language of commemoration.

For other correspondents, the strength of Orpen's painting lay in its accusation of the disappointments of the peace and its reminder that the sacrifices of the simple soldier were being forgotten. One admirer wrote: 'Your wonderful picture the 'Peace Conference' represents Real Peace because you are fed up with the mockery of peace...and covered it with a layer of paint. ${ }^{55}$ In a letter to the press, an officer described his platoon's horror at accidentally exhuming rotting French corpses, and concluded, 'Isn't this Sir Wm. Orpen's comment on 1923 AD? Are not the "demented boy soldiers" symbolical of the world's doomed young lives, condemned to death and disease by the futility of Versailles that mocks the cenotaphed warrior?' ${ }^{56}$ Orpen's decision to replace the political and military leaders with the coffin of the unknown British soldier found widespread support among the public, for reasons of both personal remembrance and political criticism. 
It is noteworthy that no-one, not even Orpen's harshest critics, argued that the painting ought to have included the statesmen whom he had originally been commissioned to paint. Condemnation of the painting was solely based on the spectral, decaying soldiers, which offended those who preferred their memorials to be untainted. In fact, the critics were in the minority. Once Orpen's intentions had been explained, the majority of newspapers approved of the painting, even if they found the image uncomfortable. The dissonance between the solemn ceremony of the coffin and its grotesque guards echoed the complex and contradictory nature of many people's feelings towards the war. In the post-war climate of disillusionment, respectful remembrance was important, but so was the need to remember the war honestly. This did not necessarily translate into anti-war sentiment but was part of the debt that the living owed the dead. To deny the truth was to deny the validity of the sacrifices that had been made. The painting's widespread popular approval suggests that many people acknowledged and accepted this complication. As the Evening Standard perceptively noted, 'The picture is in the spirit not of 1918 or 1919 but of 1923 '. ${ }^{57}$

\section{The Imperial War Museum}

The IWM, however, had not asked for a commentary on war or peace, but a record of an event, and Orpen knew that his painting had departed radically from the original brief. When he contacted curator Charles ffoulkes [sic] to inform him that the picture was ready, he presumed that 'the Trustees will not want this for the IWM',

but offered them first option on the painting as per the terms of the original contract. ${ }^{58}$ Ffoulkes visited Orpen's studio on 3 January 1923 and was very favourably impressed. He recommended to the IWM Director General Sir Martin Conway that 
the museum should take the painting, 'as it is not only a very remarkable specimen of his work, but it would be the only symbolic picture in our collection.' ${ }^{59}$ Ffoulkes was prepared, in this instance, to depart from IWM policy. However, when Conway viewed the picture two days later, he could immediately see that 'there would be no chance of obtaining approval from the main body of our Trustees as the picture stands. ${ }^{90}$ Ffoulkes candidly admitted to Orpen that 'although they are capable and distinguished Civil Servants, there are not many of them who have what I may call very fine artistic perceptions.' ${ }^{61}$ The soldier-figures were clearly the source of the problem, and ffoulkes suggested to Orpen that he might paint them out, a suggestion Orpen rejected. ${ }^{62}$ As a compromise, it was agreed that the IWM would withhold its final decision until the Trustees could view the painting.

The Trustees of the IWM inspected To the Unknown British Soldier in France at the private view of the Summer Exhibition on 4 May and met twelve days later to consider their verdict. In the meantime, Orpen all but forced their hand with a provocative interview in the Evening Standard which headlined on its front page: 'IMPERIAL WAR MUSEUM NOT TAKING UP OPTION ON THE CANVAS.' 63 Even without this incitement to rejection, it is unlikely that the Trustees would have accepted the picture. Mostly in their late 50s and 60s, they were civil servants, dignitaries, politicians and high-ranking military officials, hardly the types likely to look favourably on a picture that had drawn hostile reactions from the conservative press. Moreover, Mond must have been mindful of the criticism that he had received when The Nation's War Pictures were exhibited at the Royal Academy in 1919. The absorption of the paintings from the British War Art and British War Memorials Committee schemes into the IWM's collection meant that he was now responsible for 
a large body of avant-garde war art. When faced with awkward questions in parliament about 'freak' pictures and the IWM's expenditure thereon, he had blamed Beaverbrook's commissioning policy and distanced himself from the modernist aesthetic. ${ }^{64}$ Although Orpen's painting could hardly be classed as avant-garde, neither did it sit comfortably within traditional military portraiture. At a meeting on 16 May, the Standing Committee of the IWM 'decided not to exercise their option.' ${ }^{65}$

Conway and ffoulkes, aware of the controversy that the picture had generated, chose the words of their rejection with care. Conway wrote to Orpen with the committee's decision 'for technical reasons' as the picture 'does not come within the terms of the original commission', and adding his own view that 'it will undoubtedly take a high place among the paintings of our time in the opinion of future generations' ${ }^{66}$ He stuck to this line in a statement to the Sunday Express on 20 May, saying, 'The picture as it now appears is all right in its way. It does not show what we wished shown - the great men of the Versailles Treaty. Therefore we must decline to buy it. ${ }^{67}$ However, in later correspondence with HM Treasury, ffoulkes gave a different reason for the painting's rejection: 'while it is an important and interesting work of art, it has not the historical significance which they consider necessary' ${ }^{68}$ 'Historical significance' for the IWM did not mean a higher artistic truth; it meant a visual record in a supposedly-neutral documentary style. ${ }^{69}$ As an artist, Orpen's value was in his technical abilities, not his artistic vision, and as a witness only to the event he had been commissioned to paint, not his wider experience of war. In this, the IWM was out of step with not only with Orpen, but with the critics, journalists and members of the public who had responded so passionately to his painting. 


\section{8: reconciliation and acceptance}

Five years later, this controversial episode reached a quiet resolution. Following the death of Earl Haig on 29 January 1928, Orpen mentioned almost casually to Conway in the course of routine correspondence that he would like to present To the Unknown British Soldier in France to the museum in memory of the Field Marshal, 'one of the best friends I ever had' ${ }^{70}$ Orpen had known Haig since 1917, but it was mostly likely Haig's dedication to the welfare of ex-servicemen and their families that prompted Orpen to make the connection to his painting. Haig was chairman of the United Service Fund and president of the Royal British Legion, an organisation he had helped to found, and thousands of former servicemen turned out voluntarily to line the processional route to Westminster Abbey for his state funeral. ${ }^{71}$ When Orpen offered to paint out the unpalatable figures, Conway magnanimously responded that 'personally I should be glad to have it just as you painted it', but by this time Orpen had decided that 'it would be better without the cherubs and ghosts'. As well dedicating the painting to Haig's memory, Orpen requested that it be hung opposite to The Signing of the Peace as 'it gives two different ideas about the whole thing' ${ }^{72}$ His view on the peace process and the maltreatment of the ordinary soldier had not changed. Ffoulkes informed Orpen that the Trustees accepted his offer 'with very great pleasure' and 'that any alteration which you see fit to make to the picture will be appreciated by them. ${ }^{73}$ Orpen duly painted out the figures and To the Unknown British Soldier in France entered the IWM's collection (fig. 4). [figure 4 near here]

The IWM issued a press release about its new acquisition, making no comment about the alterations but enclosing a photograph to allow the press to draw 
their own conclusions. ${ }^{74}$ It generated little interest. Under the heading 'Sir William Orpen Alters a Picture' the Daily Mail published before and after photographs of the painting, only commenting drily that it had 'caused considerable discussion' when first exhibited. ${ }^{75}$ The Evening Standard carried an incorrect account of the original events, claiming that the original commission had been "to paint a symbolic picture which represented both the fighting element and the Peace Conference', and that Orpen originally intended that 'as the Peace Treaty was empty, so, too, should be the picture'. ${ }^{76}$ Like the Daily Mail, it passed no comment on the revisions. Instead, Orpen received widespread press coverage that week for his society portraits on show at the Royal Academy. Public interest had moved on.

By 1928 there was little war art being produced on canvas; the great public commissions of the later war years and early post-war years had come to an end. Only memorials were being commissioned, either as monumental sculpture, or occasionally, as at the private Sandham memorial chapel at Burghclere, canvas panels for permanent installation. Stanley Spencer's chapel (1927-32) depicts neither horror nor filth, but the prosaic daily round of soldierly life, with a Christian message of redemption. ${ }^{77}$ Although this was typical of Spencer's work, most other war memorials also eschewed graphic portrayals of warfare in favour of traditional imagery. One notable exception is Charles Sargent Jagger's Royal Artillery memorial, unveiled in 1925, which portrayed realistic (and dead) rather than idealised soldiers, but this unconventional imagery remained exceptional. ${ }^{78}$ Instead, the baton of candour seems to have passed from visual art to literature. Many of the seminal war memoirs and novels were published at this time: Edmund Blunden's Undertones of War in 1928, Robert Graves' Goodbye to All That and the English translation of 
Erich Maria Remarque's All Quiet on the Western Front in 1929, and Siegfried Sassoon's Memoirs of an Infantry Officer in 1930. There was a memorial element to these works too. Daniel Todman has pointed out that horror and commemoration in literature were not mutually exclusive, and the graphic descriptions of violence in some of the early war novels actually served to heighten the heroism of those involved..$^{79}$

Almost a decade passed between the commissioning and acceptance of To the Unknown British Soldier in France, and the painting's story reflects the changing relationship between art and the memory of the war during that period. At the time of the armistice and in the early post-war years, the IWM trustees were in the minority. They wanted to commemorate the peace process through a traditional and paternalistic representation of great men at a great event. Critics and the public, however, had been conditioned by exhibitions such as The Nation's War Paintings to expect more from war art, and they looked to artists to distil their first-hand experiences of the war into a symbolic representation of a deeper truth. By 1923 this truth encompassed not only the war, but the social and economic hardships faced by ex-servicemen. Respectful commemoration of the dead did not preclude an acknowledgement of the horrors of war or the disappointments of peace, and many people were able to hold in tandem the importance of remembering the sacrifices of the common soldier with due recognition for the harsh reality of war. Orpen's hybrid painting represented for them an emotional truth about war, as witnessed by an artist who had spent months at the front, and whose sympathies lay with the ordinary soldier. It was not an anti-war monument, although it was, perhaps, an anti-peace process monument. 
By 1928, when war art was being produced principally for memorials, public and critical interest in canvas painting had returned to peace-time subjects, and eyewitness accounts of the conflict's horrors were being recorded in print, not paint. The resumption of Orpen's thriving portrait practice meant that he no longer benchmarked himself against the younger generation of avant-garde artists, and the IWM were grateful to receive the altered painting, even if it did not record an actual event. In the long run, it was the works commissioned by Masterman and Bennett, many of which were avant-garde and communicated a symbolic rather than a literal truth, that came to dominate the discourse of war art. In art-historical terms, To the Unknown British Soldier in France is something of an anomaly, neither traditional nor avant-garde, but for a few years in the 1920s it was a site in which passionate debates about the war and its memory were played out. 


\section{Notes}

1. Nora, Les Lieux de mémoire, Winter, Sites of Memory. See Todman, The Great War and Modern Memory for an analysis of the memory of the war across the twentieth century through culture.

2. Brandon, Art and War, 5.

3. For a full account see Malvern, Modern Art, Britain and the Great War, 17-90.

4. Winter and Prost, The Great War in History, 174.

5. Wellington, Exhibiting War, 106.

6. Hutchison, "Accurate to the Point of Mania", 43.

7. Wellington, Exhibiting War, 105.

8. Harries, The War Artists, 122.

9. Cited in Gough, A Terrible Beauty, 131.

10. Arnold Bennett, foreword to 'Void of War' exhibition (1918), cited in Gough, "A concentrated utterance of total war", 270.

11. Hynes, A War Imagined, 283.

12. Bank of England Inflation Calculator. Available at: https://www.bankofengland.co.uk/monetary-policy/inflation/inflation-calculator (accessed: 5 November 2019).

13. Gough, A Terrible Beauty, 196-7; Harries, The War Artists, 152; Hynes, A War Imagined, 294-5.

14. The only comprehensive modern biography is Arnold, Orpen.

15. Arnold, Orpen, 308-310.

16. Orpen published his war memoirs in 1921 as An Onlooker in France.

17. This painting can be seen at https://www.iwm.org.uk/collections/item/object/20883 (accessed: 5 November 2019).

18. Daily Telegraph, 28 May 1918, cited in Arnold, Orpen, 25. 
19. Imperial War Museum (IWM), ART/WA1/090 (First World War Art Archive: Sir

William Orpen, 1918) Orpen to Yockney, 16 November 1918; Yockney to Orpen, 19

November 1918; Yockney to French Ambassador in London, 4 December 1918.

20. IWM, ART/WA1/091 (First World War Art Archive: Sir William Orpen, 1919) Davies to Mond, 12 February 1919.

21. IWM, ART/WA1/091 Orpen to Yockney, 14 March 1919.

22. IWM, ART/WA1/091 Conway to Riddell, 26 March 1919.

23. IWM, ART/WA1/091 Orpen to Mond, 18 April 1919; ffoulkes to Orpen, 2 May 1919.

24. Orpen, Onlooker in France, 223.

25. Wickham, “1920”.

26. National Gallery of Ireland (NGI), PD/GRA/353 (Graves Collection of William Orpen Letters) Illustrated letter from William Orpen to Mrs St. George with a preliminary sketch of To the Unknown British Soldier in France.

27. Ibid.

28. Morning Post, 5 May 1923, 7.

29. Interview with Orpen, Daily News, 9 May 1923, 5.

30. Orpen, "Unknown British Soldier," 528-9.

31. Harrington, "Religious and spiritual themes", 161.

32. Branson, Britain in the Nineteen Twenties, 69.

33. Arnold, Orpen, 432.

34. Orpen donated all his war work to the nation and donated the royalties from An Onlooker in France to the Haig Fund.

35. Gibbs, Realities of War; Gibbs, Back to Life; NGI, PD/GRA/353.

36. J. Middleton Murry, "The War Pictures at the Royal Academy”, Nation, 20 December 1919, 419-20; R. H. W., “The Nation's War Paintings”, 1375.

37. Upstone, 'Love and Beauty', 46.

38. Wilcox, "1923”.

39. Morning Post, 5 May 1923, 7.

40. "Royal Academy." Daily Mail, 5 May 1923, 7.

41. Westminster Gazette, 8 May 1923, 1, 5.

42. Daily News, 7 May 1923, 1.

43. Ibid. 
44. Daily Herald, 8 May 1923, 7.

45. Daily Express, 5 May 1923, 1, 3; Manchester Guardian, 5 May 1923, 12; Hull Daily

Mail, 5 May 1923, 2.

46. Manchester Guardian, 8 May 1923, 8.

47. Observer, 13 May 1923, 12.

48. Evening Standard, 7 May 1923, 1, 9.

49. Orpen, "Unknown British Soldier", 528-9.

50. For example, Illustrated London News, 12 May 1923; The Times, 7 May 1923; Sunday Express, 6 May 1923.

51. Daily Graphic, 7 May 1923, 1.

52. Donald S. Munro, letter to the Sunday Times, 17 June 1923, in William Orpen's cuttings file, private collection.

53. Letter from Henry W. French, n.d., Orpen's cuttings file.

54. Letter from J. Buckett, 7 May 1923, Orpen's cuttings file.

55. Letter from J.P., 9 May 1923, Orpen's cuttings file.

56. Letter from Leonard Selden (publication unknown), Orpen's cuttings file.

57. Evening Standard, 7 May 1923, 1, 9.

58. IWM, ART/WA1/092 (First World War Art Archive: Sir William Orpen, 1920-7), Orpen to ffoulkes, 19 December 1922.

59. IWM, EN1/1/MUS/020/6 (Director General's Correspondence), ffoulkes to Conway, 3 January 1923.

60. IWM, ART/WA1/092, ffoulkes to Orpen, 6 January 1923.

61. Ibid.

62. IWM, ART/WA1/092, Orpen to ffoulkes, 8 January 1923.

63. Evening Standard, 7 May 1923, 1, 9.

64. Harries, The War Artists, 152.

65. IWM, EN1/1/MUS/020/6, Précis of the Meetings of the Standing Committee, 16 May 1923.

66. IWM, EN1/1/TRE/030/1 (Treasury: Treasury Solicitor), Copy of letter, Conway to Orpen, 17 May 1923.

67. Sunday Express, 20 May 1923, 1.

68. IWM, EN1/1/COB/024 (Standing Committee and Board of Trustees: Sir William Orpen), ffoulkes to Secretary, H.M. Treasury, 6 July 1923.

${ }^{69}$ Wellington, Exhibiting War, 116-7. 
70. IWM, ART/WA1/093 (First World War Art Archive: Sir William Orpen, 1928), Orpen to Conway, 20 February 1928.

71. Prior and Wilson, "Haig, Douglas".

72. IWM, ART/WA1/093, Orpen to Conway, 25 February 1928.

73. IWM, ART/WA1/093, ffoulkes to Orpen, 21 March 1923.

74. IWM, ART/WA1/093, Press release, 3 and 7 May 1928.

75. Daily Mail, 9 May 1928, 20.

76. Cited in the Irish Times, 10 May 1928, 8. I have not been able to identify any such article in the London Evening Standard from 1-9 May 1928 so it is possible that the Irish Times misattributed the source of the article.

77. For a comprehensive account of the Sandham Memorial Chapel see Malvern, Modern Art, Britain and the Great War, 162-177.

78. For a discussion of this memorial, see Black, "Neither beasts", 167-71.

79. Todman, The Great War, 24.

\section{Acknowledgements}

I would like to thank Dr Michael Redley, who supervised the postgraduate dissertation on which this article is based. Thanks also to the family of Sir William Orpen, who kindly allowed me to access and reproduce excerpts from the artist's private papers, and to Peter Johnston and my two anonymous reviewers for their helpful comments on the original manuscript.

\section{Declaration of interest}

No potential conflict of interest was reported by the author. 


\section{Bibliography}

Arnold, Bruce. Orpen: mirror to an age. London: J. Cape, 1981.

Black, Jonathan. “"Neither Beasts, nor Gods, but Men”. Constructions of Masculinity and the Image of the Ordinary British Soldier or 'Tommy' in the First World War Art of: C.R.W. Nevinson (1889-1946); Eric Henri Kennington (18881960) and Charles Sargent Jagger (1885-1934)'. Unpublished PhD. thesis, University College, London, 2003.

Brandon, Laura. Art and War. London: I. B. Tauris, 2007.

Branson, Noreen. Britain in the nineteen twenties. London: Wiedenfeld and Nicholson, 1975.

Cork, Richard. A bitter truth: avant-garde art and the Great War. New Haven and London: Yale University Press, 1994.

Gibbs, Philip. Back to life. London: W. Heinemann, 1920.

Gibbs, Philip. Realities of War. London: W. Heinemann, 1920.

Gough, Paul. A terrible beauty: British artists in the First World War. Bristol: Sansom, 2010.

Harries, Meirion, and Susie Harries. The War Artists: British official war art of the twentieth century. London: M. Joseph, 1983.

Harrington, Peter. "Religious and Spiritual themes in British academic art during the First World War." First World War Studies, 2, no. 2 (2011), 145-164. doi: $10.1080 / 19475020.2011 .613242$

Hutchison, Margaret. “ "Accurate to the Point of Mania”: Eyewitness Testimony and Memory Making in Australia's Official Paintings of the First World War.' Australian Historical Studies, 46, no.1 (2015), 27-44, doi: 10.1080/1031461X.2014.996574

Hynes, Samuel. A War Imagined. London: Pimlico, 1992. 
Malvern, Sue. Modern Art, Britain and the Great War: witnessing, testimony and remembrance. New Haven and London: Yale University Press, 2004.

Nora, Pierre. Les Lieux de Mémoire. Paris : Gallimard, (4 vols) 1984-1992.

Orpen, William. "To the Unknown British Soldier in France." The English Review, June 1923, 528-9. ProQuest British Periodicals.

Orpen, William. An Onlooker in France: a critical edition of the artist's war memoirs. Edited by Robert Upstone and Angela Weight. London: Paul Holberton, 2008.

Prior, Robin, and Trevor Wilson. 2011 "Haig, Douglas, first Earl Haig (1861-1928), army officer." Oxford Dictionary of National Biography.

R.H.W., "The Nation's War Paintings at Burlington House”, The Athenaeum, (4677), 1375, ProQuest British Periodicals.

Todman, Daniel. The Great War: myth and memory. London: Hambledon, 2005.

Upstone, Robert. "Love and Beauty in an Age of Extremes." In William Orpen: Politics, Sex \& Death, edited by Robert Upstone, 7-51. London: Philip Wilson, 2005.

Wellington, Jennifer. Exhibiting War: The Great War, Museums, and Memory in Britain, Canada, and Australia. Cambridge: Cambridge University Press, 2017.

Wickham, Annette. “1920: an Uneasy Peace”. The Royal Academy Summer Exhibition: a Chronicle, 1769-2018. Paul Mellon Centre online publication, https://chronicle250.com/1920 (accessed: 5 November 2019).

Wilcox, Timothy. "1923: The Male Body as History and Symbol”. The Royal Academy Summer Exhibition: a Chronicle, 1769-2018. Paul Mellon Centre online publication, https://chronicle250.com/1923 (accessed: 5 November 2019).

Winter, Jay. Sites of Memory, Sites of Mourning: The Great War in European cultural history. Cambridge: Cambridge University Press, 1995.

Winter, Jay. and Prost, Antoine. The Great War in History: Debates and Controversies, 1914 to the Present. Cambridge: Cambridge University Press, 2005 


\section{Figure captions}

Figure 1. William Orpen, To the Unknown British Soldier in France (original version, 1922). From a photograph, oil on canvas. Imperial War Museum.

Figure 2. William Orpen, The Signing of the Peace in the Hall of Mirrors, Versailles (1919). Oil on canvas. Imperial War Museum.

Figure 3. William Orpen, Blown Up (1917). Pencil and watercolour on paper. Imperial War Museum.

Figure 4. William Orpen, To the Unknown British Soldier in France (1922, altered 1928). Oil on canvas. Imperial War Museum. 